\title{
A Microcomputer Database Program for Sweetpotato Breeding and Trials
}

\author{
P.C. St. Amand ${ }^{1}$ and D.R. La Bonte ${ }^{2}$ \\ Department of Horticulture, Louisiana State University Agricultural \\ Center, Louisiana State University Experiment Station, Baton Rouge, \\ LA 70803-2120
}

Additional index words. Ipomoea batatas, computer software

This database for sweetpotato [Ipomoea batatas (L.) Lam.] is written in the FoxBASE+ database language for microcomputers (IBM-compatible personal computers). The program allows users with limited computer knowledge and instruction to quickly use the program's various features. The database framework consists of five pull-down menus (TEST, FIELD-PLANS, REPORTS, UTILITIES, and DATAFORMS), each containing one or more options. Each option has prompts (print, escape, save, etc.) to direct the user.

The foremost purpose of the sweetpotato database program is to allow assemblage of pertinent data on individual selections (lines) using various test options. An ancillary role of the database is to maintain a comprehensive record of all aspects of the breeding program.

By using the Add/Edit Selections option available in the TEST menu, a breeder can assemble a record for any given selection. This option asks the user for the parentage, release name (if applicable), maturity, seed production, total carotenoids, and percent dry matter. Root and canopy descriptors adapted from Huaman (1987) are also included in this option. A powerful feature of the database program is its capacity to summarize

Received for publication 8 Sept. 1991. Accepted for publication 27 Sept. 1991. Approved for publication by the Director of the Louisiana Agricultural Experiment Station as manuscript no. 90-284200. Research support provided in part by the Louisiana Advertisement and Development Commission. Mention of trade names does not constitute a guarantee or warranty of the product nor does it imply endorsement over similar products. The cost of publishing this paper was defrayed in part by the payment of page charges. Under postal regulations, this paper therefore must be hereby marked advertisement solely to indicate this fact. ${ }^{1}$ Research Associate. Current address: Dept. of Horticulture, North Carolina State Univ., Box 7609, Raleigh, NC 27695.

${ }^{2}$ Assistant Professor, to whom reprint requests should be addressed. test data for individual lines and to list the plant descriptors in a printout by selecting the Print All Information option in the REPORTS main menu. For example, yield data entered into the TEST menu Yield option are presented as an overall mean and standard deviation for each market grade for all yield tests in which the line has been entered. Yield data are also presented on a percentage basis with respect to three user-specified control cultivars. A similar summary is given for the following self-descriptive TEST menu options: Bedding Evaluation, Baking, Canning, Fusarium Root Rot, Fusarium Wilt, Internal Cork, Java Black Rot, Root Knot Nematode, Soil Rot/Circular Spot, Bacterial Soft Rot, Grub, Banded Cucumber Beetle, and Flea Beetle. All test options are based on those commonly used by members of the National Sweetpotato Collaborators Group. This format provides a breeder with a performance profile over diverse environments and years, which is particularly useful since genotype $\mathrm{X}$ environmental interactions for yield and some quality factors are commonplace in sweetpotato (Collins et al., 1987):

All statistical applications are based on Fisher's unprotected least significant difference (LSD) procedure $(P=0.05)$ for a randomized complete-block design. Raw data are analyzed by the method of least squares. If missing data are present, a generalized inverse is computed using the G2SWEEP operator as described by Goodnight (1979). LSD and rankings are printed in a publicationready table. Test size is constrained by the number of replications and selections in concert. As the number of replications decreases, more selections can be evaluated. A typical test plot with four replications can have up to 26 lines entered. Eight replications is the maximum allowed. Some options in the TEST menu do not have statistical applications, namely Bedding Evaluation, Chlorotic Leaf Distortion, Internal Cork, and Java Black Rot. These options record reactions relative to controls.

Preparation of trials for the growing sea- son is aided by recording plot plans through the Test Plot option within the FIELD PLANS menu. A file for a given plot plan is opened, or edited if it already exists, by specifying a test name, location, and year.

The user is subsequently queried as to various dimensions of the plot, planting date, number of replications, and number of days to harvest. Any additional pertinent information (i.e., pesticide and fertilizer applications) can be recorded in a note section. A printout is available as the user exits the file. To further aid the user, location, planting date, and calculated harvest date for all trials in a given year are provided through the List All Test Names option in the REPORTS menu. All variables specified in a plot plan are transferred to the appropriate file in the TEST menu if the same trial name, location, and year are used when opening the file. Data collected on forms available in the DATAFORMS menu facilitate data entry into respective options in the TEST menu.

The REPORTS menu has several options associated with record-keeping. The options, List Selections to Maintain and List All Selections Planted, respectively, permit the user to identify extant lines and which lines are entered into what tests for a given year. The Print Lineage option reports the pedigree of a line. The Custom Query option permits the user to screen the database for lines that meet certain criteria for any number of user-specified variables (e.g., soil rot resistance, yield, maturity). Individual factors can be set to be greater than, equal to, or less than any quantitative variable, or equal to or not equal to a qualitative variable. Options within the UTILITIES menu produce and restore a copy of the data, delete unwanted tests, and rename selections. The Import Data option permits data transfer via diskettes between microcomputers. This allows all collaborative researchers who use this program to have the same data set.

Diskettes of the database program, a runtime version of the FoxBASE+ database language, and a user's guide are available from D.R.L. for a nominal charge.

\section{Literature Cited}

Collins, W.W., L.J. Wilson, S. Arrendell, and L.F. Dickey. 1987. Genotype x environment interactions in sweet potato yield and quality factors. J. Amer. Soc. Hort. Sci. 112:579-583.

Goodnight, J.H. 1979. A tutorial on the SWEEP operator. Amer. Stat. 33:149-158.

Huaman, Z. 1987. Descriptors for the characterization and evaluation of sweet potato genetic resources. Exploration, maintenance, and utilization of sweet potato genetic resources. Intl. Potato Center, Lima. p. 331-355. 